\title{
1,4-Diamino-2-butanone, a wide-spectrum microbicide, yields reactive species by metal-catalyzed oxidation
}

\author{
Chrislaine O. Soares ${ }^{a}$, Maria Julia M. Alves ${ }^{a}$, Etelvino J.H. Bechara ${ }^{\mathrm{a}, \mathrm{b}, *}$ \\ a Departamento de Bioquímica, Instituto de Química, Universidade de São Paulo, 05508-900 São Paulo, SP, Brazil \\ b Departamento de Ciências Exatas e da Terra, Instituto de Ciências Ambientais, Químicas e Farmacêuticas, Universidade Federal de São Paulo, Diadema, SP, Brazil
}

\section{A R T I C L E I N F O}

Article history:

Received 6 September 2010

Revised 22 March 2011

Accepted 28 March 2011

Available online 3 April 2011

\section{Keywords:}

1,4-Diamino-2-butanone

$\alpha$-Aminoketones

$\alpha$-Oxoaldehydes

Reactive oxygen species

Ferritin

Transferrin

Oxidative damage

Free radicals

\begin{abstract}
A B S T R A C T
The $\alpha$-aminoketone 1,4-diamino-2-butanone (DAB), a putrescine analogue, is highly toxic to various microorganisms, including Trypanosoma cruzi. However, little is known about the molecular mechanisms underlying DAB's cytotoxic properties. We report here that DAB ( $\mathrm{p} K_{\mathrm{a}} 7.5$ and 9.5) undergoes aerobic oxidation in phosphate buffer, $\mathrm{pH} 7.4$, at $37^{\circ} \mathrm{C}$, catalyzed by $\mathrm{Fe}(\mathrm{II})$ and $\mathrm{Cu}$ (II) ions yielding $\mathrm{NH}_{4}^{+}$ion, $\mathrm{H}_{2} \mathrm{O}_{2}$, and 4-amino2-oxobutanal (oxoDAB). OxoDAB, like methylglyoxal and other $\alpha$-oxoaldehydes, is expected to cause protein aggregation and nucleobase lesions. Propagation of DAB oxidation by superoxide radical was confirmed by the inhibitory effect of added SOD $\left(50 \mathrm{U} \mathrm{ml}^{-1}\right)$ and stimulatory effect of xanthine/xanthine oxidase, a source of superoxide radical. EPR spin trapping studies with 5,5-dimethyl-1-pyrroline-1-oxide (DMPO) revealed an adduct attributable to DMPO-HO", and those with $\alpha$-(4-pyridyl-1-oxide)- $N$-tert-butylnitrone or 3,5-dibromo4-nitrosobenzenesulfonic acid, a six-line adduct assignable to a DAB ${ }^{\bullet}$ resonant enoyl radical adduct. Added horse spleen ferritin (HoSF) and bovine apo-transferrin underwent oxidative changes in tryptophan residues in the presence of 1.0-10 mM DAB. Iron release from HoSF was observed as well. Assays performed with fluorescein-encapsulated liposomes of cardiolipin and phosphatidylcholine (20:80) incubated with DAB resulted in extensive lipid peroxidation and consequent vesicle permeabilization. DAB ( $0-10 \mathrm{mM})$ administration to cultured LLC-MK2 epithelial cells caused a decline in cell viability, which was inhibited by preaddition of either catalase $(4.5 \mu \mathrm{M})$ or aminoguanidine $(25 \mathrm{mM})$. Our findings support the hypothesis that DAB toxicity to several pathogenic microorganisms previously described may involve not only reported inhibition of polyamine metabolism but also DAB pro-oxidant activity.
\end{abstract}

(C) 2011 Elsevier Inc. Open access under the Elsevier OA license.
Similar to 5-aminolevulinic acid (ALA), a heme precursor implicated in acquired and inborn porphyria [1,2], and aminoacetone (AA), a threonine and glycine catabolite suggested to be related to diabetes manifestations [3,4], the microbicide 1,4-diamino-2-butanone (DAB) bears an amino group vicinal to a carbonyl group (Scheme 1 ), rendering $\mathrm{DAB}$ prone to fast enolization and subsequent metal-catalyzed oxidation by dissolved dioxygen. Reactive oxygen species, ammonium ions, and $\alpha$-oxoaldehydes are the main products of ALA and AA chemical oxidation [5-7]. $\alpha$-Oxoaldehydes such as 3,4-dioxovaleric acid and methylglyoxal, produced by ALA and AA, respectively, have been shown to be highly cytotoxic and genotoxic electrophiles $[6,8]$. They partake in electrophilic attack on amino groups of proteins and nucleobases yielding Schiff bases, Maillard adducts, and ethane DNA adducts, which are putative biomarkers of oxidative and carbonyl stress in agingrelated diseases and diabetes $[9,10]$. Protein aggregation and dysfunction due to cross-linking with these reactive dicarbonyls may underlie the clinical manifestations of such disorders.

\footnotetext{
* Corresponding author. Fax: +55 1130913869.

E-mail address: ejhbechara@gmail.com (E.J.H. Bechara).
}

Recently DAB has been reported to be toxic to several pathogens, including Trypanosoma cruzi, the etiologic agent of Chagas disease [11]. Other pathogenic microorganisms reported to be affected by DAB include Leishmania amazonensis[12], Giardia lamblia[13], and Tritrichomonas foetus[14]. It is thought that the major effect of DAB upon microorganisms is the inhibition of ornithine decarboxylase (ODC; $K_{\mathrm{i}}=0.9 \mu \mathrm{M}$ ), the enzyme that catalyzes the first step in polyamine biosynthesis culminating in cell arrest $[15,16]$. Polyamines have long been known to play fundamental roles in growth, development, cellular differentiation, macromolecular stabilization, and apoptosis [17,18].

Here, we report that DAB undergoes metal-catalyzed aerobic oxidation in phosphate buffer to yield an $\alpha$-oxoaldehyde and reactive oxygen species (ROS), which could drive oxidative damage to added ferritin, apo-transferrin, and biomimetic liposomes. Superoxide radical is shown to propagate the oxidation of DAB to 1-imino-4-amino- 2butanone, whose hydrolysis yields 4-amino-2-oxobutanal (oxoDAB) and $\mathrm{NH}_{4}^{+}$ion. As expected from Schiff-type additions, further formation of a pyrrole adduct of oxoDAB with remaining $D A B$ is demonstrated. Finally, DAB is shown to promote oxoDAB- and ROS-mediated loss of epithelial cell viability, revealing a mechanism that may contribute to the reported DAB toxicity to pathogenic microorganisms. 

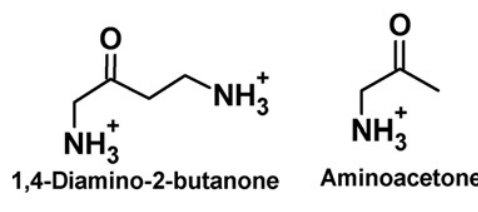

DAB

AA

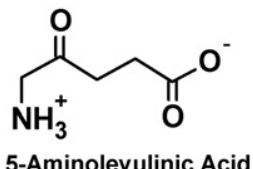

ALA

Scheme 1. Chemical structures of 1,4-diamino-2-butanone, aminoacetone, and 5aminolevulinic acid.

\section{Materials and methods}

\section{Materials}

DAB, Chelex-100, diethylenetriaminepentaacetic acid (DTPA), desferrioxamine, bovine blood $\mathrm{Cu}, \mathrm{Zn}$ superoxide dismutase (SOD), horse spleen ferritin (HoSF), bovine apo-transferrin, bovine liver catalase (CAT), ammonia diagnostic kit, $\mathrm{FeSO}_{4}, \mathrm{CuSO}_{4}$, xanthine, bovine milk xanthine oxidase, mannitol, semicarbazide, $N$-acetyl-L-cysteine (NAC), 5,5-dimethyl-1-pyrroline-1-oxide (DMPO), $\alpha$-(4-pyridyl-1-oxide)- $N$ tert-butylnitrone (POBN), Triton X-100, phosphatidylcholine, and cardiolipin were purchased from Sigma-Aldrich (St. Louis, MO, USA). Acetic acid, $\mathrm{NaOH}, \mathrm{Na}_{2} \mathrm{HPO}_{4} \cdot 12 \mathrm{H}_{2} \mathrm{O}, \mathrm{NaH}_{2} \mathrm{PO}_{4} \cdot \mathrm{H}_{2} \mathrm{O}$, and $\mathrm{NaCl}$ were supplied by Merck (Darmstadt, Germany). The spin trap 3,5-dibromo4-nitrosobenzenesulfonic acid (DBNBS) was prepared as previously described [19]. All other chemicals were of analytical grade. DAB stock solutions were prepared with degassed $18 \mathrm{M} \Omega$ Milli-Q water and kept under nitrogen atmosphere. All buffers were pretreated with Chelex100.

\section{Oxygen consumption}

Oxygen uptake was measured using a Clark-type electrode in a sealed glass chamber (Hansatech Instruments Ltd, Norfolk, UK). All experiments were carried out in air-equilibrated $100 \mathrm{mM}$ phosphate buffer, $\mathrm{pH} 7.4$, at $37^{\circ} \mathrm{C}$.

\section{EPR spin trapping experiments}

EPR spectra of DMPO, POBN, and DBNBS spin adducts were recorded in a Brucker EMX spectrometer at room temperature. All spectra were recorded after $20 \mathrm{~min}$ of reagent incubation in $100 \mathrm{mM}$ phosphate buffer, $\mathrm{pH} 7.4$, at $25^{\circ} \mathrm{C}$. The instrumental conditions were as follows: microwave power, $20.21 \mathrm{~mW}$; modulation amplitude, 0.15 $\mathrm{mT}$; time constant, 164.84; and gain, $1.12 \times 10^{6}$.

\section{UV-Vis and fluorescence spectral analyses}

DAB decay at $37{ }^{\circ} \mathrm{C}$ was monitored in the region of 200 to $500 \mathrm{~nm}$ in a Varian Cary 50 Bio UV-Vis spectrophotometer (Australia Pty Ltd) and spectrofluorimetrically using SpexFluorolog 1681 equipment (Horiba Scientific, Ann Arbor, MI, USA). Ferritin and apo-transferrin were incubated with 1.0-10 mM DAB in $100 \mathrm{mM}$ phosphate buffer, $\mathrm{pH} 7.4$, at $37^{\circ} \mathrm{C}$. Tryptophan fluorescence data were obtained at $280 / 345 \mathrm{~nm}$ after $2 \mathrm{~h}$ incubation using a Spectra Max $\mathrm{M} 2^{\mathrm{e}}$ microplate reader (Molecular Devices, Sunnyvale, CA, USA).

\section{Product analysis}

DAB oxidation products from $3.0 \mathrm{mM}$ DAB in air-equilibrated $100 \mathrm{mM}$ phosphate buffer, $\mathrm{pH} 7.4$, at $37^{\circ} \mathrm{C}$, under agitation for $2 \mathrm{~h}$, were analyzed by HPLC. Products were separated using a Waters HPLC system (Waters Corp., Milford, MA, USA) equipped with a photodiode array detector and a fluorescence detector. The HPLC conditions were adapted from Itakura et al. [20] as follows: isocratic mobile phase methanol:water $(10: 90, \mathrm{v} / \mathrm{v})$ with $0.2 \%$ acetic acid, Supelco column $\mathrm{C}_{18}(250 \times 4.6 \mathrm{~mm}, 5 \mu \mathrm{m}$ particle size $)$, flow rate $0.70 \mathrm{ml} \mathrm{min}^{-1}$. All analyses were performed at room temperature.

Electrospray ionization mass spectra (ESI/MS) were obtained in an LCD Ion Max Advanced spectrometer (Thermo Finnigan, Waltham, MA, USA) in positive mode under the following conditions: voltage, $10 \mathrm{~V}$; nitrogen used as the sheath gas at $20 \mathrm{psi}$; temperature, $275^{\circ} \mathrm{C}$; spray voltage, $4.5 \mathrm{kV}$; capillary voltage, $10 \mathrm{~V}$; tube lens offset, $5 \mathrm{~V}$. Fractions collected under the HPLC peaks were concentrated and injected directly into the ESI/MS spectrometer.

Ammonia was assayed spectrophotometrically in the final reaction mixture using a commercial kit (Ammonia Diagnostic Kit; Sigma) based on the NADPH-dependent enzymatic amination of $\alpha$-oxoglutarate.

\section{Ferritin iron release}

Horse spleen ferritin was purified on Sephadex G-25 as described by Oteiza et al. [21] to remove loosely bound iron. Protein concentration was determined by the classic method of Bradford [22]. Iron released by DAB from ferritin was followed by measuring the increase in absorbance at $530 \mathrm{~nm}$ due to chelation of $\mathrm{Fe}$ (II) by bathophenanthroline sulfonate $\left(A_{530}=22.14 \mathrm{~cm}^{-1} \mathrm{mM}^{-1}\right)$. Experimental conditions were $1.0 \mathrm{mM}$ bathophenanthroline sulfonate and $2.5 \mathrm{mg} \mathrm{ml}^{-1} \mathrm{HoSF}$ in $100 \mathrm{mM}$ phosphate buffer, $\mathrm{pH} 7.4$, at $37^{\circ} \mathrm{C}$, in the presence of 1.0-10 mM DAB with or without $5-400 \mathrm{U} \mathrm{ml}^{-1} \mathrm{SOD}$, incubated for $2 \mathrm{~h}$.

\section{Lipid peroxidation}

Liposomes made from phosphatidylcholine:cardiolipin (80:20) were prepared by sonication according to Oteiza and Bechara [23]. To evaluate the effects of DAB on lipid peroxidation, $0.60 \mathrm{mM}$ phospholipid

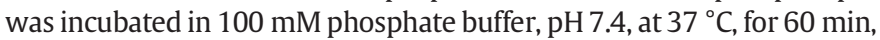
in the presence of $1.0-5.0 \mathrm{mM}$ DAB and $3 \mu \mathrm{M}$ Fe(II)EDTA or $\mathrm{Cu}$ (II). The reaction was stopped by addition of $4 \%$ (final concentration) tertbutylated hydroxytoluene. Lipid peroxidation was determined by HPLC using fluorimetric detection of thiobarbituric acid-malondialdehyde (TBA-MDA) adducts against a standard curve obtained with 1,1,3, 3tetramethoxypropane [24,25], after minor modification as follows. The separation was achieved using a Supelco column $\mathrm{C}_{18}(250 \times 4.6 \mathrm{~mm}$, $5 \mu \mathrm{m}$ particle size) and a mobile phase made from $\mathrm{KH}_{2} \mathrm{PO}_{4}-\mathrm{KOH}(5 \mathrm{mM}$, $\mathrm{pH} 7.0)$ and methanol (50:50 v/v), with a flow rate of $0.7 \mathrm{ml} \mathrm{min}^{-1}$. The TBA-MDA adduct was monitored at $\lambda_{\mathrm{ex}}=515 \mathrm{~nm}$ and $\lambda_{\mathrm{em}}=553 \mathrm{~nm}$.

5(6)-Carboxyfluorescein (CF) was encapsulated into phosphatidylcholine:cardiolipin liposomes (80:20) prepared by sonication according to Oteiza et al. [23], under self-quenching conditions $(0.10 \mathrm{M})$. CF release from DAB-treated liposomes was measured as the increase in fluorescence at $550 \mathrm{~nm}$ (excitation $490 \mathrm{~nm}$ ) due to dilution of the probe in the external medium. Liposomes $(0.60 \mathrm{mM}$ phospholipids) were incubated in $100 \mathrm{mM}$ phosphate buffer, $\mathrm{pH} 7.4$, at $37^{\circ} \mathrm{C}$, for $24 \mathrm{~h}$. Complete release was obtained by addition of Triton X-100 ( $0.2 \%$ final concentration). CF release was calculated as $\left(F_{1} / F_{0}\right) \times 100$, where $F_{1}$ is the fluorescence at $550 \mathrm{~nm}$ in the absence of Triton X-100, and $F_{0}$ is the fluorescence at $550 \mathrm{~nm}$ in the presence of Triton X-100.

\section{Cell culture and treatments}

LLC-MK2, a monkey kidney epithelial cell line, was maintained in minimum essential medium (MEM) (Invitrogen, Carlsbad, CA, USA) supplemented with $10 \%$ fetal bovine serum (FBS) (Cultilab, Campinas, $\mathrm{SP}$, Brazil) at $37{ }^{\circ} \mathrm{C}$ and $5 \% \mathrm{CO}_{2}$. For cell viability assays, LLC-MK2 cells were seeded in a 24-well plate at a density of $5 \times 10^{4}$ cells/well $24 \mathrm{~h}$ before the treatments. Cell viability was determined using 3-[4,5dimethylthiazol-2-yl]-2,5-diphenyl tetrazolium bromide (MTT; Sigma-Aldrich). Viability was determined by the level of reduced MTT measured at $570 \mathrm{~nm}$, expressed as a percentage of the control as a reference. 


\section{Statistical analysis}

Data represent at least three independent experiments, expressed as means $\pm \mathrm{SD}$. The Student $t$ test or ANOVA was employed for statistical analysis, using a significance of $p<0.05$.

\section{Results}

\section{Oxygen uptake}

Addition of DAB (3.0 mM) to normally aerated $100 \mathrm{mM}$ phosphate buffer $\left(\left[\mathrm{O}_{2}\right] \sim 200 \mu \mathrm{M}[26]\right), \mathrm{pH} 7.4$, immediately triggers oxygen consumption (Fig. 1 , curve a). Maximum oxygen uptake rates $\left(k_{\mathrm{obs}}\right.$, $\mathrm{s}^{-1}$ ) respond linearly to the increase in DAB concentration (1.0$5.0 \mathrm{mM}$ ) and allow the calculation of an apparent second-order rate constant, $k_{2}$, as $0.100 \pm 0.007 \mathrm{M}^{-1} \mathrm{~s}^{-1}$ (Fig. 1, inset). The addition of desferrioxamine or DTPA $(1.0 \mathrm{mM})$ to the system inhibited oxygen consumption by DAB (Fig. 1, curves $b$ and $c$ ), suggesting the presence of contaminant metals that are putatively able to catalyze oxidation reactions by dioxygen [27]. Accordingly, medium supplementation with 3.0 or $10 \mu \mathrm{M}$ Fe(II)EDTA or $3.0 \mu \mathrm{M}$ aqueous $\mathrm{Cu}(\mathrm{II})$ resulted in the acceleration of oxygen consumption by DAB (Fig. 1, curves d, e, and f). Controls consisting of buffer and added transition metals do not show oxygen consumption (Fig. 1, curves $g$ and $h$ ). Copper(II)-catalyzed DAB oxidation was threefold faster than with $\mathrm{Fe}(\mathrm{II})$ EDTA. Transition metal ions catalyze both the initiation and the propagation steps once they originate hydroxyl radical by Fentontype reactions, which can initiate further events of DAB hydrogen abstraction and oxygen uptake [28].

Addition of scavengers of reactive oxygen species to the reaction mixture inhibits oxygen uptake (Table 1 ). With regard to the $\mathrm{Fe}(\mathrm{II})$ EDTA $(3 \mu \mathrm{M})$-catalyzed DAB $(3.0 \mathrm{mM})$ oxidation, the observed inhibitory effects of $\mathrm{Cu}, \mathrm{ZnSOD}$ (35\%), semicarbazide (43\%), CAT (20\%), and mannitol (36\%) attest to the intermediacy of $\mathrm{O}_{2}^{--}, \mathrm{H}_{2} \mathrm{O}_{2}$, and $\mathrm{HO}^{\circ}$ species, respectively. Autoxidation of ferrous ion may contribute as a source of $\mathrm{O}_{2}^{--}$radical that can initiate $\mathrm{DAB}$ oxidation. CAT and GSH decreased the observed rate of $\mathrm{Cu}$ (II)-catalyzed oxygen uptake by 50 and $83 \%$, respectively, whereas the other scavengers had no significant effects, suggesting formation of high amounts of $\mathrm{H}_{2} \mathrm{O}_{2}$

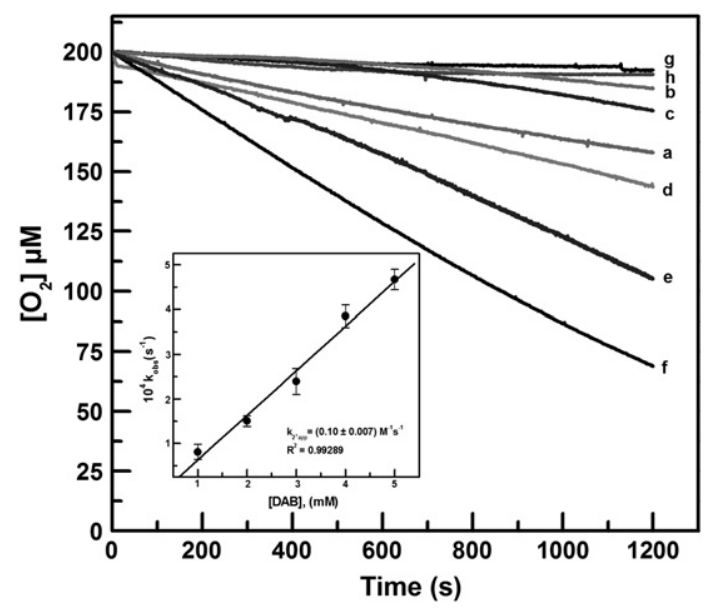

Fig. 1. Effects of metal chelator and $\mathrm{Fe}(\mathrm{II}) \mathrm{EDTA}$ or $\mathrm{Cu}(\mathrm{II})$ on oxygen consumption by DAB. Shown are the time courses of oxygen consumption by $3.0 \mathrm{mM}$ DAB (curve a) alone or in presence of (curve b) $1.0 \mathrm{mM}$ desferrioxamine, (curve c) $1.0 \mathrm{mM}$ DTPA, (curve d) $3 \mu \mathrm{M}$ Fe(II)EDTA, (curve e) $10 \mu \mathrm{M} \mathrm{Fe}$ (II)EDTA, and (curve f) $3 \mu \mathrm{M} \mathrm{Cu}$ (II) and the controls in the absence of DAB, (curve g) $3.0 \mu \mathrm{M} \mathrm{Fe}$ (II)EDTA and (curve h) $3.0 \mu \mathrm{M} \mathrm{Cu}$ (II). The inset shows the effect of DAB concentration on the observed autoxidation rate. Calculation of $k_{\text {obs }}$ and $k_{2}$ app values assumed $\left[\mathrm{O}_{2}\right]$ of $200 \mu \mathrm{M}$. The data represent the mean values obtained from three independent experiments.
Table 1

Effects of ROS scavengers on the rate of oxygen uptake by DAB in the presence of transition metal ions.

\begin{tabular}{llr}
\hline System & \% Inhibition & \\
\cline { 2 - 3 } & $\mathrm{Cu}(\mathrm{II})_{\mathrm{aq}}$ & Fe(II)EDTA \\
\hline Catalase & $52 \pm 0.94$ & $20 \pm 0.96$ \\
Mannitol & $8.65 \pm 1.38$ & $36 \pm 8.07$ \\
Semicarbazide & No & $43 \pm 3.26$ \\
SOD & $2.69 \pm 0.49$ & $35 \pm 1.58$ \\
GSH & $83 \pm 0.27$ & $9.35 \pm 3.01$ \\
\hline
\end{tabular}

Oxygen uptake by $3 \mathrm{mM}$ DAB in $100 \mathrm{mM}$ phosphate buffer, pH 7.4 , at $37^{\circ} \mathrm{C}$ in the presence of $3 \mu \mathrm{M} \mathrm{Cu}$ (II) or Fe(II)EDTA was measured. Catalase, $4.5 \mu \mathrm{M}$; mannitol, $50 \mathrm{mM}$; semicarbazide, $5 \mathrm{mM}$; SOD, $50 \mathrm{U} \mathrm{ml}^{-1}$; and GSH, $1 \mathrm{mM}$.

by the $\mathrm{Cu}(\mathrm{II})$-catalyzed reaction. Hydrogen peroxide may originate highly oxidizing hydroxyl radical by a Fenton-type reaction [27], thereby amplifying DAB oxidation by hydrogen abstraction.

Co-oxidation of $\mathrm{DAB}$ and xanthine in the presence of xanthine oxidase, a well-known source of $\mathrm{O}_{2}^{--}$, confirms (Fig. 2, curve c) the ability of $\mathrm{O}_{2}^{--}$ions to abstract one electron from $\mathrm{DAB}$, thus initiating and propagating the oxidative reaction. Previously, Machino and Fridovich [29] reported that dihydroxyacetone phosphate oxidation by dioxygen, a reaction propagated by superoxide radical, is triggered upon addition of xanthine/xanthine oxidase as well.

That $\mathrm{H}_{2} \mathrm{PO}_{4}^{-}$ion acts as an bifunctional acid-base catalyst of DAB enolization, as previously found for ALA [30] and AA [5], is supported by the increasing rates of oxygen uptake measured at higher concentrations of phosphate (Fig. 3B) [31]. Enolates are known to be more easily oxidized than the corresponding carbonyl forms [32]. The bell-shaped $\mathrm{pH}$ profile of DAB oxidation peaks at roughly 7.8, probably reflecting the overlap of two titration curves: the ascendant portion is probably due to DAB acid dissociation $\left(\mathrm{p} K_{\mathrm{a}}=7.5\right.$; inset, Fig. $3 \mathrm{~A}$ ), thus favoring enolization, and above $\mathrm{pH} 7.8$, the decrease in $\mathrm{H}_{2} \mathrm{PO}_{4}^{-}$concentration ( $\mathrm{p} K_{\mathrm{a}}$ of $\mathrm{H}_{2} \mathrm{PO}_{4}^{-}=7.2$; Fig. $3 \mathrm{~B}$ ).

\section{EPR spin trapping studies}

EPR spin trapping studies with DMPO (Fig. 4A), POBN (Figs. 4B and C), and DBNBS (Fig. 4D) were conducted in normally aerated phosphate buffer to detect and possibly identify oxygen- and carbon-centered radical intermediates. $A$ four-line spectrum $\left(\alpha_{N}=\alpha_{H}=1.47 \mathrm{mT}\right)$

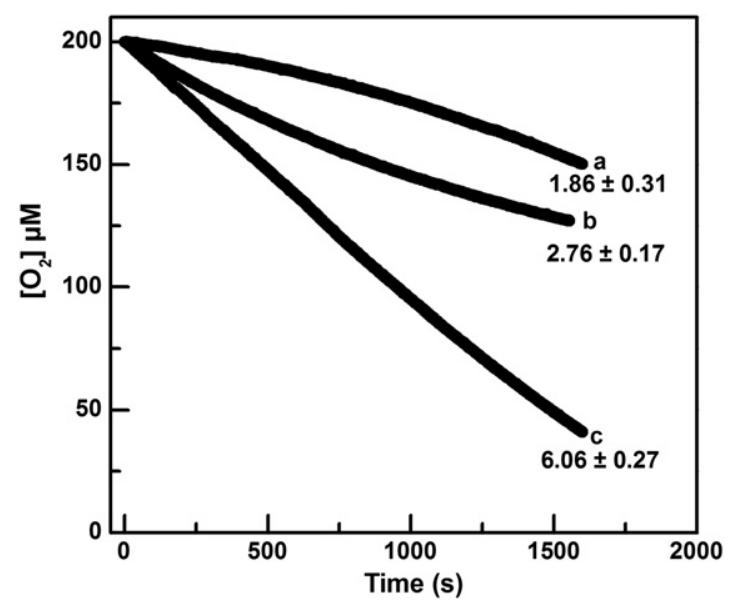

Fig. 2. Co-oxidation of $D A B$ and xanthine in the presence of xanthine oxidase. Shown are time courses containing (curve a) $3.0 \mathrm{mM}$ DAB alone, (curve b) xanthine $(0.3 \mathrm{mM}) /$ xanthine oxidase $(25 \mu \mathrm{M})$, or (curve $\mathrm{c}$ ) $\mathrm{DAB}+$ xanthine/xanthine oxidase. The numbers represent the mean values of reaction rates $\left(\mu \mathrm{M} \mathrm{min}{ }^{-1}\right)$ obtained from three independent experiments. 
A

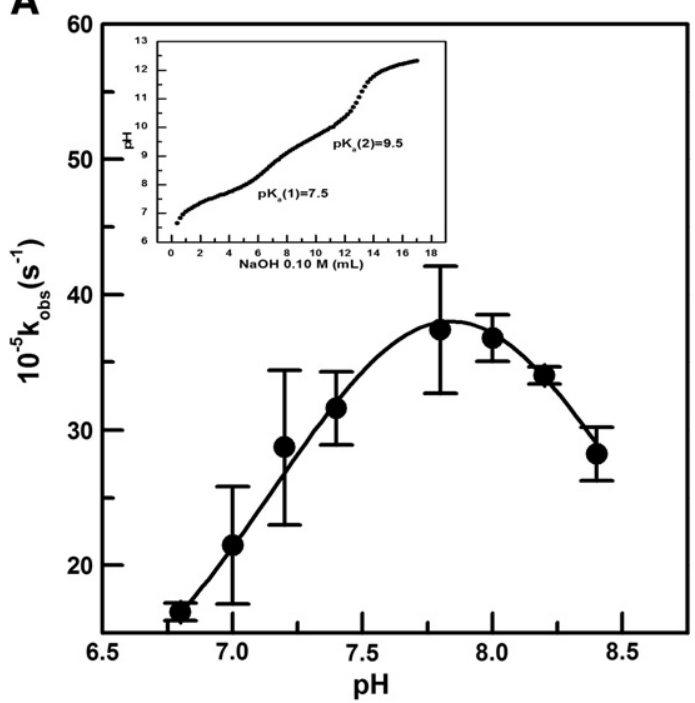

B

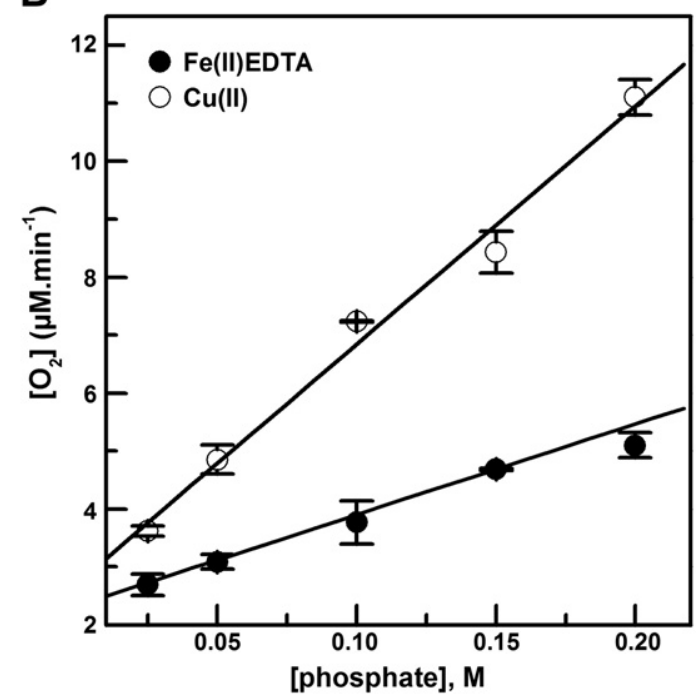

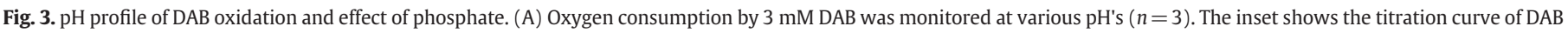

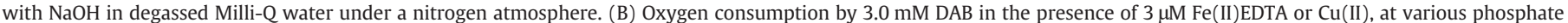
concentrations $(n=3)$. Ionic strength was kept constant using a $0.52 \mathrm{M} \mathrm{NaCl}$ stock solution.

assignable to the DMPO-HO adduct [33] was found, probably formed from decomposition of the DMPO- $\mathrm{O}_{2}^{--}$adduct as suggested by the quenching effect of added $50 \mathrm{U} \mathrm{ml}^{-1}$ SOD (Fig. 4A) and methyl radical formation when in the presence of dimethyl sulfoxide (not shown). In the presence of $\mathrm{Fe}(\mathrm{II}) \mathrm{EDTA}$ or $\mathrm{Cu}(\mathrm{II})$, the spin trapping experiments revealed no significant signal intensification. However, SOD $\left(50 \mathrm{U} \mathrm{ml}^{-1}\right)$ addition slightly decreased the EPR signal, and CAT ( $4.5 \mu \mathrm{M})$ completely abolished the signal from both iron- (not shown) and copper-containing (Fig. 4A) systems, which stresses the role of hydroxyl radical as a key DAB-oxidizing intermediate [7,34].

Spin trapping experiments with POBN revealed a stable major sixline signal with $\alpha_{\mathrm{N}}=1.5 \mathrm{mT}, \alpha_{\mathrm{H}}=0.19 \mathrm{mT}$ (Fig. 4B) that can be attributed to a carbon-centered radical [33], probably the resonant enoyl radical $\mathrm{NH}_{2} \mathrm{CH}^{*} \mathrm{COCH}_{2} \mathrm{CH}_{2} \mathrm{NH}_{3}^{+}$, as previously showed by Monteiro et al. when studying another $\alpha$-aminoketone, namely ALA [30]. A minor six-line signal with $\alpha_{\mathrm{N}}=1.5 \mathrm{mT}, \alpha_{\mathrm{H}}=0.32 \mathrm{mT}$ also appears, which is tentatively assigned to the POBN adduct formed by trapping the oxygen-centered resonant form of the DAB enoyl radical species. Contribution of the two canonic forms of the DAB resonant enoyl radical to the EPR spectrum is simulated in Fig. 4B. Therein, the time course of the EPR spectra shows slow increase in the minor DAB adduct. Hyperfine coupling constants of POBN adducts with carboncentered and oxygen-centered radicals are long known to exhibit similar values [33]. The concentration of the major POBN-DAB ${ }^{*}$ radical adduct increases upon increasing the DAB concentration when in presence of Fe(II)EDTA (Fig. 4C). No EPR signal was detected in the absence of metal. Additionally, the concentration effect of DAB in the $\mathrm{Cu}$ (II)-catalyzed reaction was not as intense as that observed with $\mathrm{Fe}$ (II)EDTA. Addition of SOD (50 $\left.\mathrm{U} \mathrm{ml}^{-1}\right)$ decreased partly the signal amplitude, whereas CAT $(4.5 \mu \mathrm{M})$ completely abolished the EPR signal. These data support the hypothesis that both superoxide and hydroxyl radicals contribute to formation of the DAB enoyl radical.

On the other hand, DBNBS spin trapping studies endorsed the formation of a carbon-centered radical, characterized by a six-line spectrum with $\alpha_{\mathrm{N}}=1.21 \mathrm{mT}, \alpha_{\mathrm{H}}=0.48 \mathrm{mT}$ (Fig. 4D). Accordingly, the EPR signal was intensified upon increasing the concentration of DAB and attenuated when SOD or CAT was added (data not shown). A similar EPR spectrum was obtained for a putative DBNBS-ALA radical adduct [36]. The observed asymmetry of the EPR spectrum depicted by Fig. 4D may be due to the presence of yet unidentified minor radicals.

\section{Product analysis}

Like ALA and AA [5,30], DAB produces $\mathrm{NH}_{4}^{+}$ion by oxidation at $3.0 \mathrm{mM}$ in normally aerated $100 \mathrm{mM}$ phosphate buffer, $\mathrm{pH} 7.4$, at $37^{\circ} \mathrm{C}$, after 2 h incubation: $100 \pm 20 \mu \mathrm{M}(n=9)$ from DAB alone, $140 \pm 10 \mu \mathrm{M}$ $(n=9)$ from DAB plus $3 \mu \mathrm{M}$ Fe(II)EDTA, and $220 \pm 20 \mu \mathrm{M}(n=9)$ from DAB plus $3 \mu \mathrm{M} \mathrm{Cu}$ (II). The $\mathrm{NH}_{4}^{+}$concentration values produced in the presence of different catalysts are statistically different $(p<0.05$; ANOVA) and are expected to be limited by the concentration of dissolved oxygen, known to be approximately $200 \mu \mathrm{M}$ in $100 \mathrm{mM}$ phosphate buffer at $37^{\circ} \mathrm{C}$ [26]. When studied in pure oxygen-purged buffer, the $\mathrm{NH}_{4}^{+}$concentration in the final reaction mixture of the $\mathrm{Cu}(\mathrm{II})$ catalyzed system was threefold higher $(570 \pm 50 \mu \mathrm{M}, n=9)$ than in airequilibrated buffer, compared to $70 \pm 10 \mu \mathrm{M}(n=9)$ under argon.

The product expected from DAB oxidation, the $\alpha$-oxoaldehyde oxoDAB, was not detected by HPLC analysis after derivatization with 1,2-benzenediamine [35]. Instead, as predictable by oxoDAB Schiff condensation with excess DAB, pyrrole derivatives were found by HPLC and MS analyses as shown below.

Fig. 5A shows the HPLC traces at 275 and $310 \mathrm{~nm}$ of DAB oxidation products after $2 \mathrm{~h}$ incubation in $\mathrm{Fe}(\mathrm{II}) \mathrm{EDTA}$-containing phosphate buffer (Fig. 5A, inset). Three fractions with retention times of 4.1, 4.4, and 5.8 min were collected, corresponding to compounds with $\lambda_{\max }$ at 310,275 , and $310 \mathrm{~nm}$, respectively. The HPLC/fluorescence detection traces allowed the product collected at $4.1 \mathrm{~min}$ to be identified as efficiently fluorescent compared to the others $\left(\lambda_{\mathrm{ex}}=326 \mathrm{~nm}\right.$ and $\lambda_{\mathrm{em}}=412 \mathrm{~nm}$, Fig. 5B, inset).

The fractions collected under the HPLC peaks were analyzed by mass spectrometry using direct infusion in the EPI mode (Figs. 6A, B, and $\mathrm{C}$ ). The fraction collected at $4.1 \mathrm{~min}$ revealed the presence of an abundant ion with $m / z 183$, and a minor ion with $m / z 167$, whereas that collected at $5.8 \mathrm{~min}$ showed an $\mathrm{m} / \mathrm{z} 187$ ion as the major component, a significant concentration of the $\mathrm{m} / \mathrm{z} 183$ ion, and a minor ion with $\mathrm{m} / \mathrm{z}$ 167. Finally, the fraction collected at $4.4 \mathrm{~min}\left(\lambda_{\max }=326 \mathrm{~nm}\right)$ contains the molecular ion $\mathrm{m} / \mathrm{z} 167$ and a minor ion with $\mathrm{m} / \mathrm{z} 183$ (Fig. 6C). The molecular ions $[\mathrm{M}+\mathrm{H}]^{+}$could tentatively be assigned to the condensation product of DAB with oxoDAB $\left(\mathrm{C}_{8} \mathrm{H}_{17} \mathrm{~N}_{3} \mathrm{O}_{2}, m / z=187\right)$, followed by its cyclization to a oxoDAB-derived pyrrolone $\left(\mathrm{C}_{8} \mathrm{H}_{12} \mathrm{~N}_{3} \mathrm{O}_{2}\right.$, $m / z=183$ ), whose second cyclization yields an oxoDAB dipyrrolone derivative $\left(\mathrm{C}_{8} \mathrm{H}_{11} \mathrm{~N}_{2} \mathrm{O}_{2}, m / z=167\right)$ (see Scheme 2, under Discussion). 
A

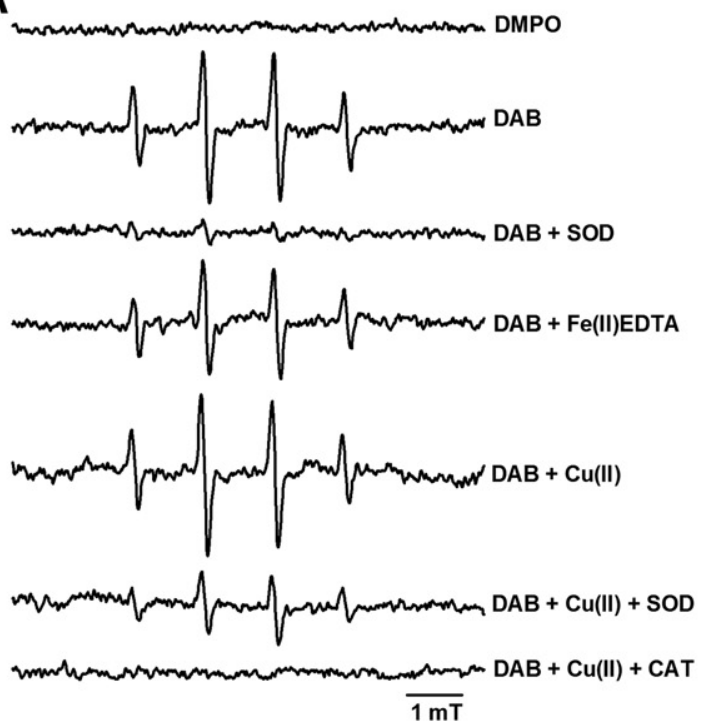

C

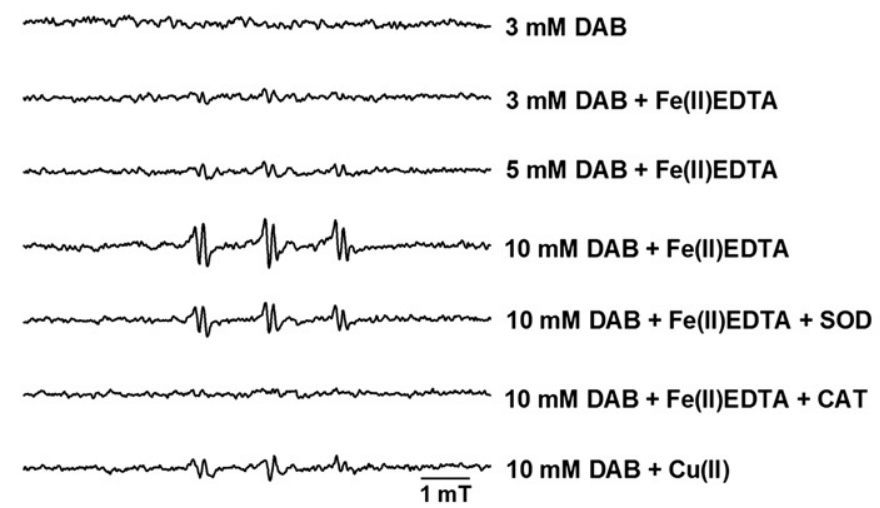

B

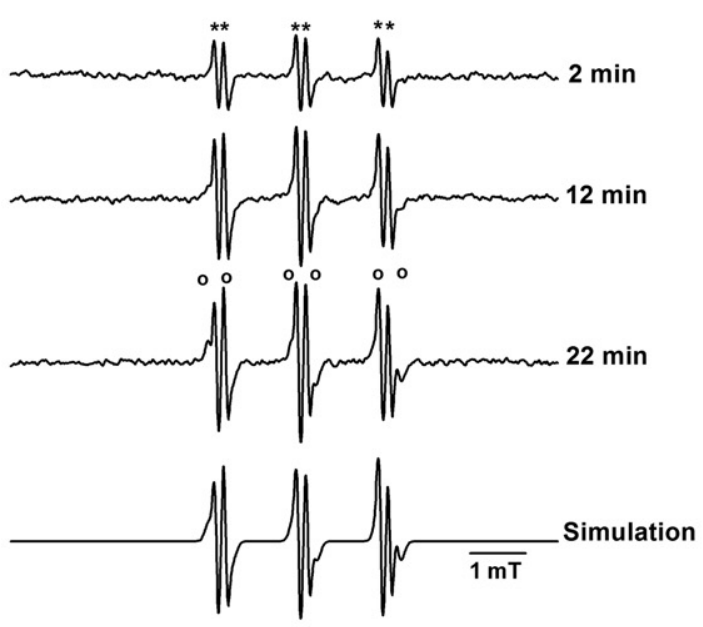

D

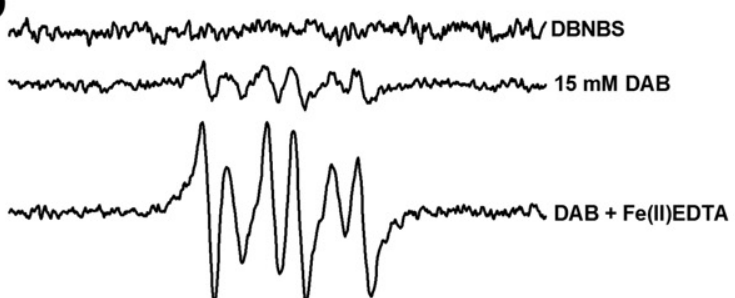

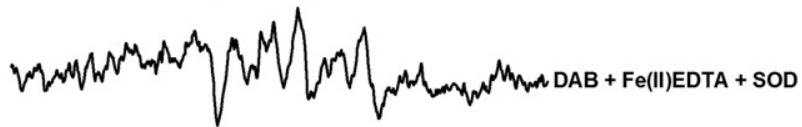

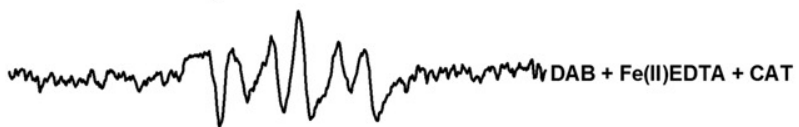

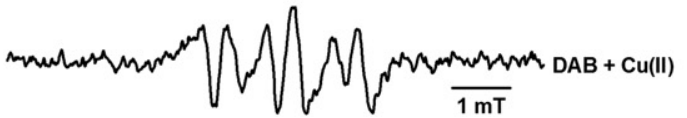

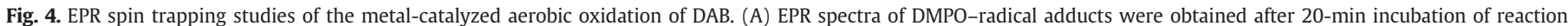

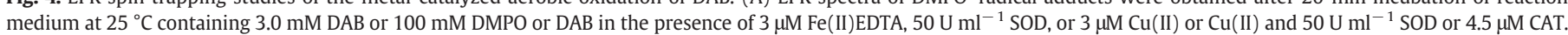

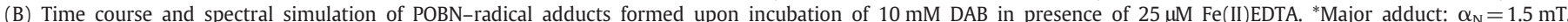

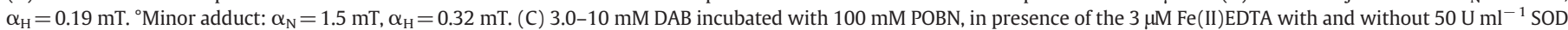

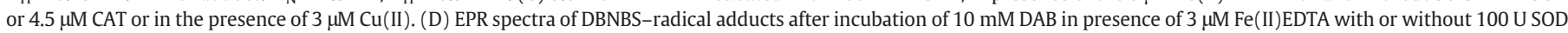
or $7.5 \mu \mathrm{M}$ CAT or in the presence of $\mathrm{Cu}(\mathrm{II})$.The data represent the mean values obtained from five independent experiments.

The main fragments of each molecular ion are consistent with the assigned structures: $\mathrm{C}_{8} \mathrm{H}_{17} \mathrm{~N}_{3} \mathrm{O}_{2}-\mathrm{C}_{4} \mathrm{H}_{9} \mathrm{NO}, \mathrm{m} / z=103 ; \mathrm{C}_{8} \mathrm{H}_{12} \mathrm{~N}_{3} \mathrm{O}_{2}$ $-\mathrm{NH}_{2}, m / z=166$, and $\mathrm{C}_{8} \mathrm{H}_{12} \mathrm{~N}_{3} \mathrm{O}_{2}-\mathrm{COH}, m / z=154$; and $\mathrm{C}_{8} \mathrm{H}_{11} \mathrm{~N}_{2} \mathrm{O}_{2}$ $-\mathrm{HO}, m / z=150$, and $\mathrm{C}_{8} \mathrm{H}_{11} \mathrm{~N}_{2} \mathrm{O}_{2}-\mathrm{CHO}, m / z=137$ (not shown). The same product profile was observed for the spent reaction mixtures obtained from $\mathrm{DAB}$ alone and from the $\mathrm{Cu}(\mathrm{II})$-catalyzed $\mathrm{DAB}$ oxidation.

\section{Oxidative damage to liposomes and proteins}

Previous studies showed that superoxide and enoyl radicals generated by AA and ALA aerobic oxidation are able to liberate Fe (II) ion from HoSF [5,36]. Here, similar results were obtained by exposing ferritin to DAB (Fig. 7A). Iron release increased upon raising the $\mathrm{DAB}$ concentration and time of exposure. Accordingly, addition of 5-400 $\mathrm{U} \mathrm{ml}^{-1} \mathrm{SOD}$ to $3.0 \mathrm{mM}$ DAB inhibited the initial rate of iron release by maximally $30 \%$ (Fig. $7 \mathrm{~B}$ ).
Upon treatment with $\mathrm{DAB}$, quenching of tryptophan residue fluorescence from HoSF and apo-transferrin was observed (Fig. 8). A major quenching effect was observed in tryptophan residues of apotransferrin compared with HoSF. This is probably because tryptophan residues are more exposed in apo-transferrin than in ferritin [37].

Apo-transferrin was incubated with DAB in the presence and absence of $\mathrm{Fe}(\mathrm{II}) \mathrm{EDTA}$ or $\mathrm{Cu}(\mathrm{II})$ (Figs. 8A and B). Curiously, in comparison with the $\mathrm{Cu}$ (II)-containing system, the apo-transferrin incubation with $\mathrm{Fe}(\mathrm{II})$ EDTA showed a higher loss of tryptophan residue fluorescence.

Fig. 9 summarizes the data obtained from the studies of DAB-induced liposome peroxidation, which was enhanced by addition of either $\mathrm{Fe}$ (II) EDTA or $\mathrm{Cu}(\mathrm{II})$. Relative fluorescence increased during 24-h incubation, indicating release of carboxyfluorescein into the medium. Although the experiments to evaluate lipid peroxidation by MDA determination and liposome permeabilization were carried out at different incubation times, a linear correlation between the two methods was observed $(p<0.05$, $\left.R^{2}=0.928\right)$. 
A

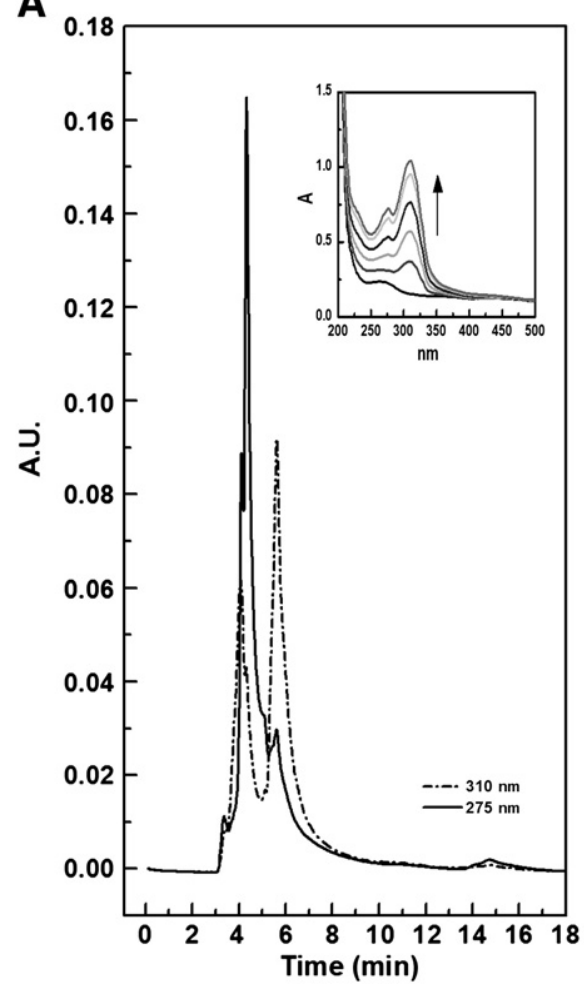

B

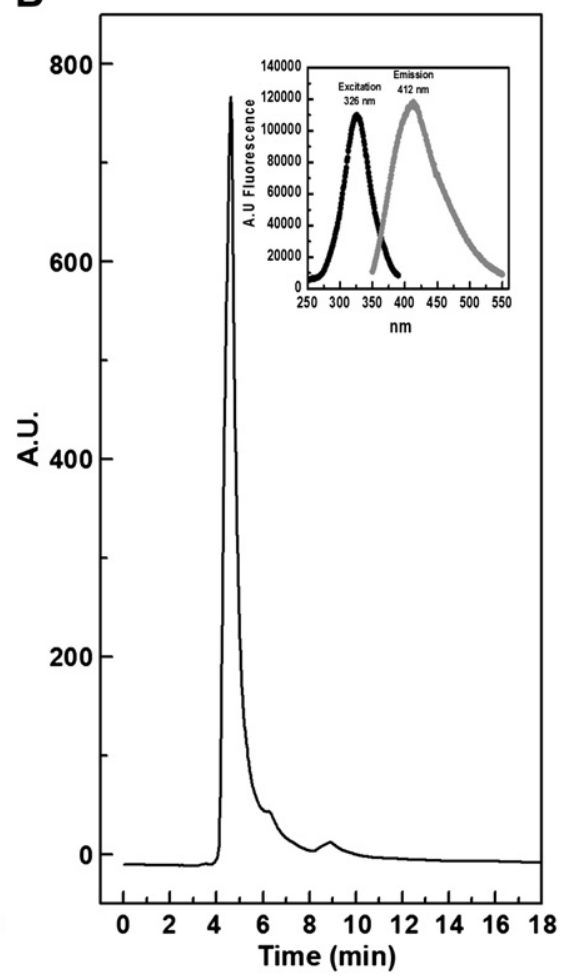

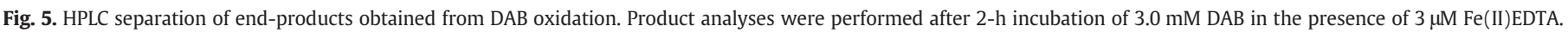

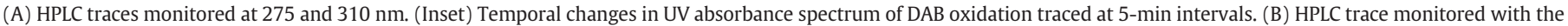
fluorescence detector $\left(\lambda_{\mathrm{ex}}=326 \mathrm{~nm} ; \lambda_{\mathrm{em}}=412 \mathrm{~nm}\right.$ ). (Inset) Excitation and emission spectra of final reaction mixture. The data represent six independent experiments.

\section{Cytotoxicity to culture cells}

A pro-oxidant activity of DAB was examined in an in vivo system by investigating the cytotoxicity of DAB in LLC-MK2 cells, a rhesus monkey kidney epithelium cell line. The viability of these cells was dramatically affected by DAB treatment, which was evaluated as $\mathrm{IC}_{50}$ ca. 1.5 mM DAB upon $24 \mathrm{~h}$ incubation. As expected, the DAB toxicity was lower at shorter incubation times (Fig. 10A).

For comparison, the oxidative action of $\mathrm{DAB}$ was assessed by addition of the DAB oxidation product $\mathrm{H}_{2} \mathrm{O}_{2}(50-200 \mu \mathrm{M})$ and methylglyoxal (0.25-1.0 mM), an $\alpha$-oxoaldehyde analogue of oxo$\mathrm{DAB}$, to the cell cultures. A decline in cell viability was induced by $\mathrm{H}_{2} \mathrm{O}_{2}$ and methylglyoxal in LLC-MK2 cells at concentrations in the same range as those expected from DAB oxidation products in aerated medium, in which dissolved oxygen is ca. $200 \mu \mathrm{M}$ (Fig. 10B). These data suggest that DAB cytotoxicity to mammalian cells can be attributed to oxidative stress. Accordingly, supplementation of cell medium with CAT $(4.5 \mu \mathrm{M})$ or aminoguanidine $(25 \mathrm{mM})$, a scavenger of $\alpha$-oxoaldehydes [38] and inhibitor of polyamine/diamine oxidases [39], provided significant protection of the cells against DAB toxicity (Fig. 10C). Addition of NAC, a thiol reductant, inhibited DAB-promoted loss of cell viability. There was little involvement of superoxide, however, as SOD supplementation had no effect on cell viability (Fig. 10C).

\section{Discussion}

$\mathrm{DAB}$, a diamino analogue of putrescine, is a competitive inhibitor of ODC in several pathogenic microorganisms such as T. cruzi[11], L. amazonensis[12], G. lamblia[13], Entamoeba invadens[40], Aspergillus nidulans[15], and Candida albicans[41]. Therefore, administration of millimolar DAB to several types of cells is expected to cause a significant decrease in polyamine contents, consequently leading to a notable decline in cell proliferation [11-13]. Accordingly, DAB reportedly promotes cell architecture disorganization, mitochondrial dysfunction, and increased lipid peroxidation [11,13]. In this context, it is important to clarify the relationship of DAB cytotoxicity and oxidative stress.

We demonstrate here that DAB undergoes metal-catalyzed oxidation propagated by $\mathrm{O}_{2}^{--}$yielding oxyradicals (Figs. $1-4$ ), $\mathrm{NH}_{4}^{+}$ ion, and oxoDAB, a potentially cytotoxic $\alpha$-oxoaldehyde [42] (Scheme 2). This reaction is preceded by phosphate-catalyzed DAB enolization (Fig. 3A). In vivo, one can predict an electrophilic attack of oxoDAB on proteins and DNA [10] followed by covalent modification ultimately leading to loss of protein function and DNA mutation, respectively. This hypothesis is supported here by Schiff conjugation of oxoDAB with DAB itself to pyrrolone derivatives, as demonstrated by HPLC-MS studies (Figs. 5 and 6 ).

The rates of oxygen consumption by DAB in the presence of transition metal ions (Figs. 1 and $3 \mathrm{~B}$ ) indicate that the reaction in the presence of $\mathrm{Cu}(\mathrm{II})$ is at least three times faster than with the same concentration of Fe(II)EDTA. The observed higher inhibition by added SOD or semicarbazide, both efficient superoxide radical scavengers, in the $\mathrm{Fe}(\mathrm{II})$ EDTA-catalyzed $\mathrm{DAB}$ than with $\mathrm{Cu}(\mathrm{II})$ is consistent with a superoxide-propagated process (Table 1 ). Similar effects of SOD and CAT in the iron-catalyzed oxidation of AA and ALA have been observed previously as well $[5,30]$. In turn, the observed inhibitory effects of CAT and GSH on metal-catalyzed DAB oxidation indicate that $\mathrm{H}_{2} \mathrm{O}_{2}$ plays a more important role in the $\mathrm{Cu}(\mathrm{II})$-catalyzed reaction than in that with $\mathrm{Fe}(\mathrm{II}) \mathrm{EDTA}$, perhaps because of higher superoxide dismutation catalyzed by $\mathrm{Cu}$ (II) [43] (Scheme 2). Probably, oxidation of enol DAB in presence of $\mathrm{Fe}(\mathrm{II}) \mathrm{EDTA}$ or $\mathrm{Cu}(\mathrm{II})$ occurs by two contributing mechanisms. Two-electron transfer from a $\mathrm{DAB}-\mathrm{Cu}(\mathrm{I})$ complex to dioxygen producing $\mathrm{H}_{2} \mathrm{O}_{2}$ prevails with copper, whereas the DAB-Fe (II) complex would transfer just one electron to dioxygen to form superoxide radical, one of the propagation intermediates and a source of $\mathrm{H}_{2} \mathrm{O}_{2}$ by dismutation. In both cases, $\mathrm{DAB}$ enoyl radical is formed and 
A

A 100

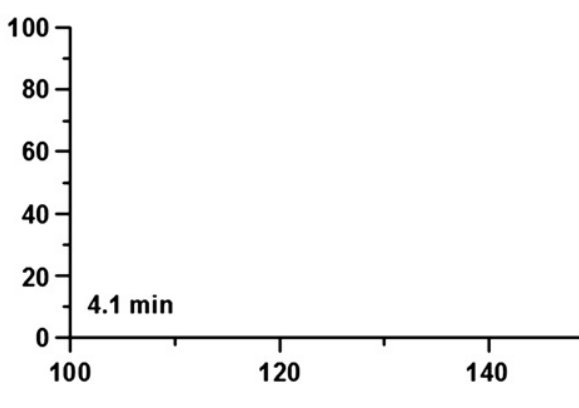

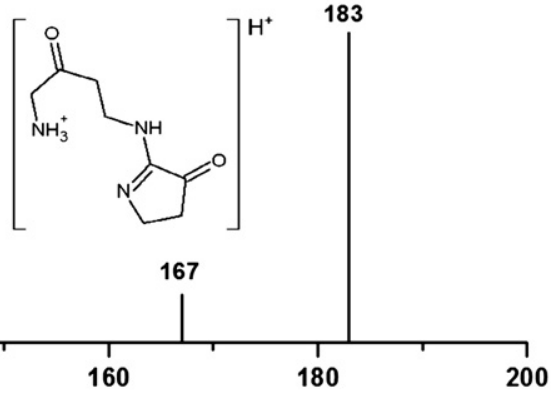

167
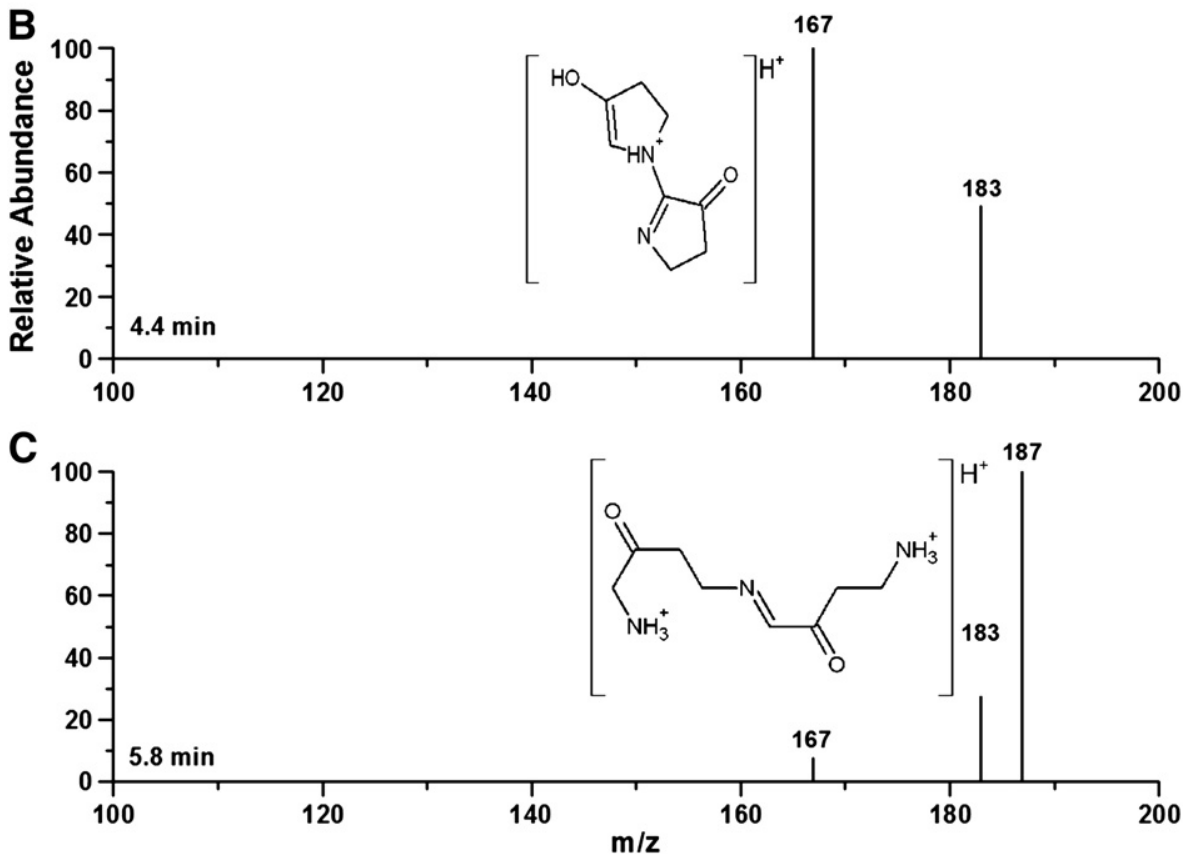

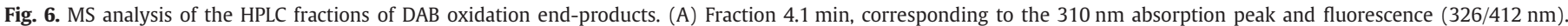
(B) Fraction 4.4 min peak elution, corresponding to the $275 \mathrm{~nm}$ peak. (C) Fraction $5.8 \mathrm{~min}$ is related to the $310 \mathrm{~nm}$ peak. The data represent six independent experiments.

consumed by dioxygen, thus propagating the reaction. Accordingly, SOD inhibits iron-catalyzed oxygen consumption but exhibits little effect on the presence of copper.

The EPR spin trapping experiments with DMPO (Fig. 4A) confirm the hypothesis of superoxide and hydroxyl radical production by DAB oxidation. The slight effect of SOD and remarkable inhibition by CAT on the amplitude of the four-line EPR signal characteristic of a DMPO-HO' adduct support the idea of $\mathrm{H}_{2} \mathrm{O}_{2}$ as a key agent in the metal-catalyzed DAB oxidation. Moreover, experiments with POBN and DBNBS suggest that the formation of the hypothetical resonant enoyl radical (DAB $\left.{ }^{\circ}\right)$ is indeed dependent on ROS, in accordance with the observed quenching effect of SOD or CAT on the EPR signal intensities (Scheme 2, Figs. 4B, C, and $D$ ). These results partly reproduce earlier studies under similar experimental conditions with ALA and AA, two other $\alpha$-aminoketones $[5,30,36]$.

We also show here that DAB induces oxidative damage to liposomes and iron-carrier proteins, namely ferritin and transferrin. Acquiring iron is a fundamental step in the development of a pathogen [44]. All iron that protozoan parasites need for growth is delivered by transferrin or ferritin of the host cells [45]. Ferritin is an iron-storage protein that functions in iron homeostasis and detoxification by sequestering iron within its core [46,47]. We suggest that DAB enoyl radical is the main agent of $\mathrm{Fe}(\mathrm{II})$ release from ferritin because increasing amounts of SOD added to the reaction mixture reached a plateau at 30\% inhibition (Fig. 7B). This was also verified when conducting similar experiments with AA and ALA [5,36]. Furthermore, $\alpha$-aminoketones reportedly promote structural damage to the ferritin structure, leading to loss of $\alpha$ helix content and concomitant decrease in ferroxidase activity and tryptophan fluorescence intensity [48,49]. DAB-induced decay of tryptophan fluorescence of apo-transferrin, a crucial protein synthesized to bind excess iron in the blood circulation, was also observed (Figs. 8B and C) [50]. The observed higher quenching of tryptophan fluorescence in apo-transferrin than in ferritin may result from the facts that (i) apo-transferrin $(80 \mathrm{kDa})$ is much smaller than ferritin (460 kDa), implying that its tryptophan residues are more exposed to the medium, and (ii) the absence of iron in apo-transferrin contributes positively to the quantum yield of fluorescence of its tryptophan residues [37,51].

Possible pro-oxidant activity of DAB was tested on the viability of LLCMK2 mammalian cells exposed to the toxicant. A mammalian cell line was chosen as a first step to further investigate the microbicide action of $\mathrm{DAB}$ on the same cell line infected with $T$. cruzi DAB showed to be cytotoxic to the cell cultures with an $\mathrm{IC}_{50}$ value of $1.5 \mathrm{mM}$ during $24 \mathrm{~h}$ incubation (Fig. 10A). That the DAB oxidation products are implicated in the observed cytotoxicity was demonstrated by the protective effect of added CAT and aminoguanidine (Fig. 10C). Considering that the DAB oxidation rate constant measured in vitro is low $\left(k_{2}\right.$ app $\left.=0.10 \mathrm{M}^{-1} \mathrm{~s}^{-1}\right)$, it is possible that internalized DAB is preferentially oxidized by polyamine/diamine oxidases present in the cell $[13,52]$. Accordingly, polyamine/diamine oxidases catalyze the oxidative deamination of biogenic amines and polyamines generating stoichiometric amounts of $\mathrm{H}_{2} \mathrm{O}_{2}, \mathrm{NH}_{4}^{+}$and a correspondent aldehyde, which are able to induce cell 


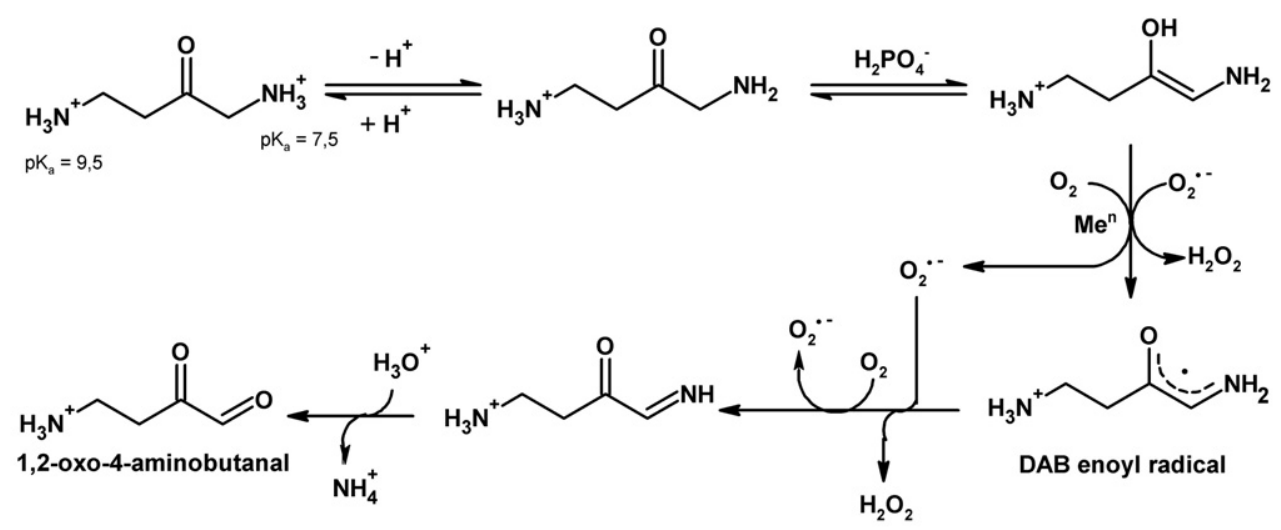

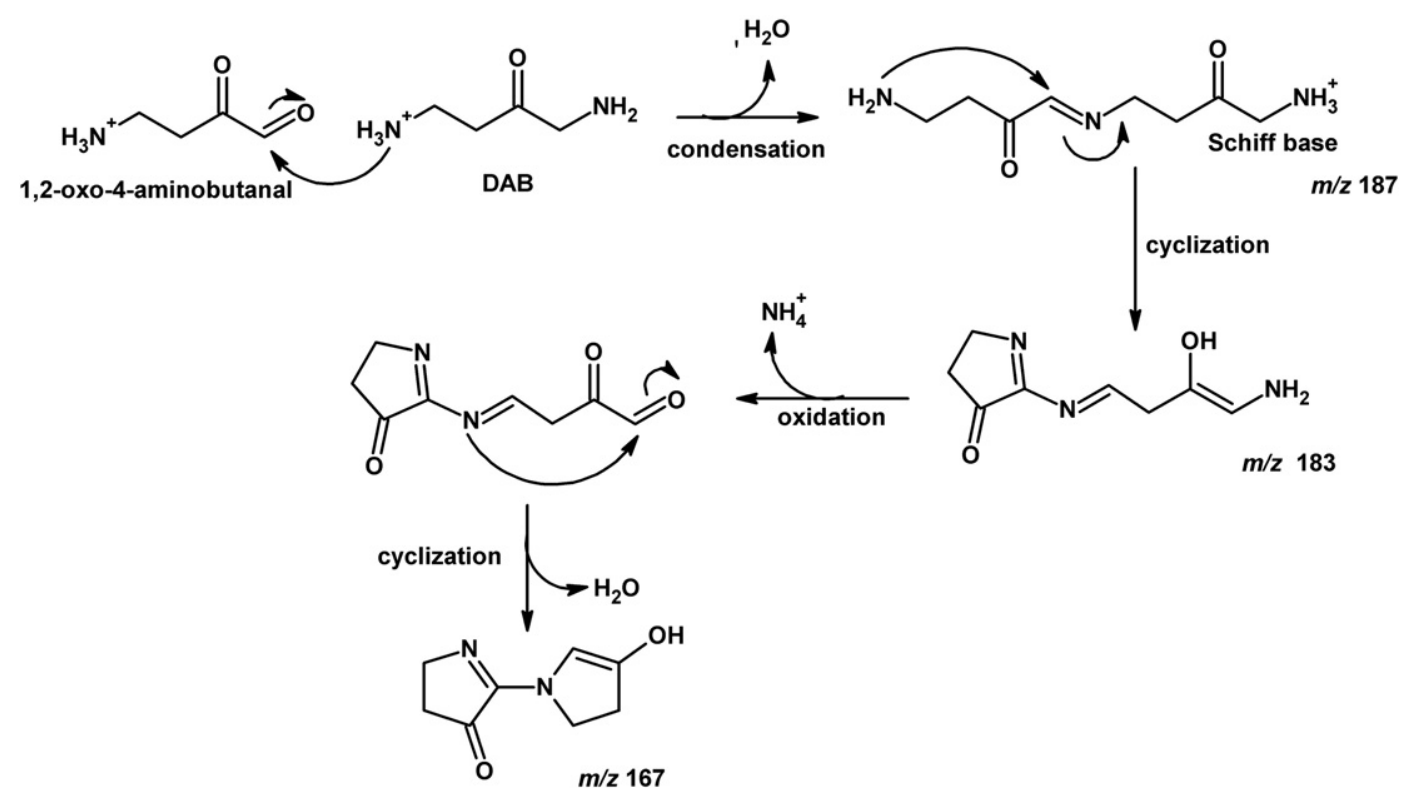

Scheme 2. Chemical mechanism proposed for metal-catalyzed DAB aerobic oxidation.

death in several cell lines [53]. The putative pro-oxidant effects of DAB reported here rely on the fact that ODC is a tightly regulated and shortlived enzyme (lifetime in the range 10-20 min) in mammalian cells [54], which thereby may minimize the effect of DAB as an ODC inhibitor.

A

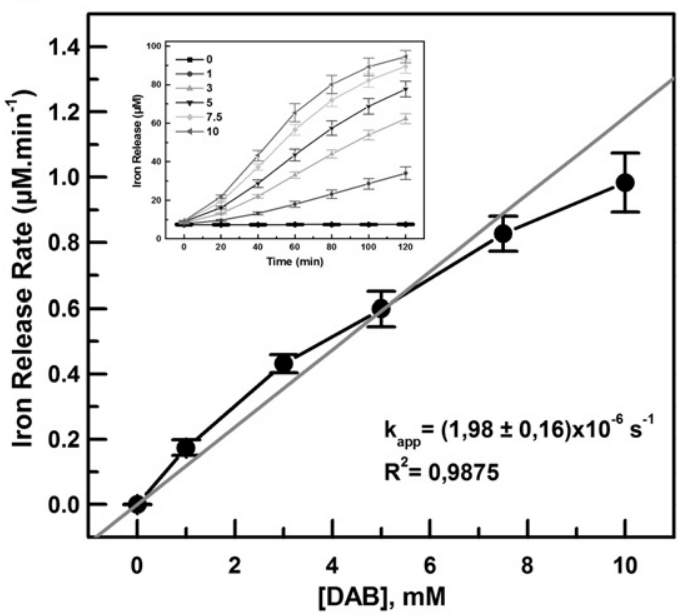

Menezes et al. [11] and Maia et al. [13] reported that DAB administration to T. cruzi epimastigotes and to G. lamblia cultures inhibits cell proliferation, increases the extent of lipid peroxidation, induces remarkable mitochondrial destruction, and promotes cell architecture

B

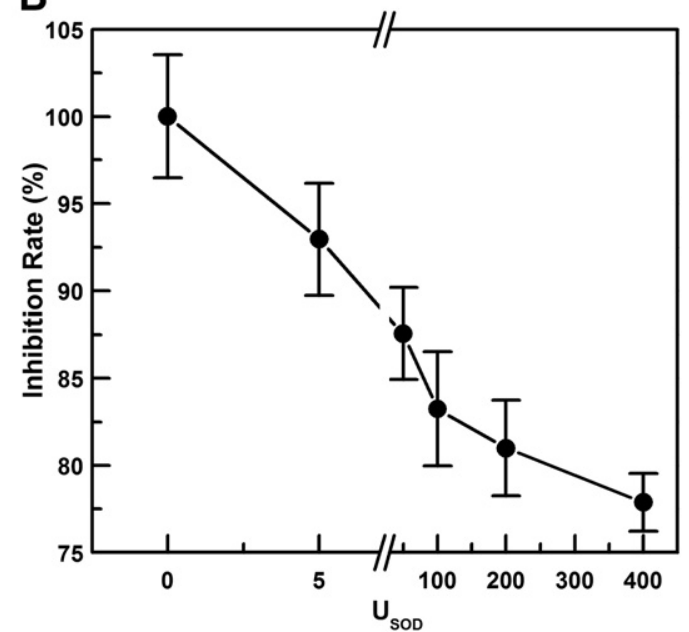

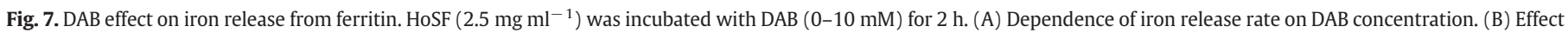
of SOD (5-400 $\left.\mathrm{U} \mathrm{ml}^{-1}\right)$ on the rate of iron release in the presence of $3.0 \mathrm{mM}$ DAB. The data represent the mean values obtained from three independent experiments. 
A

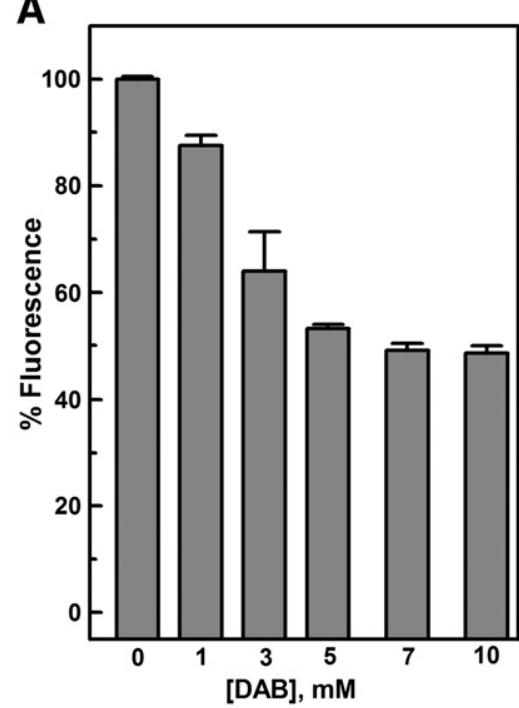

B

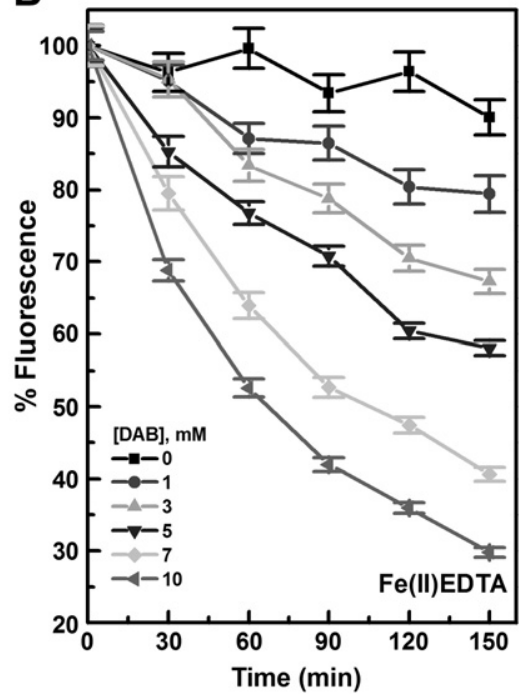

C

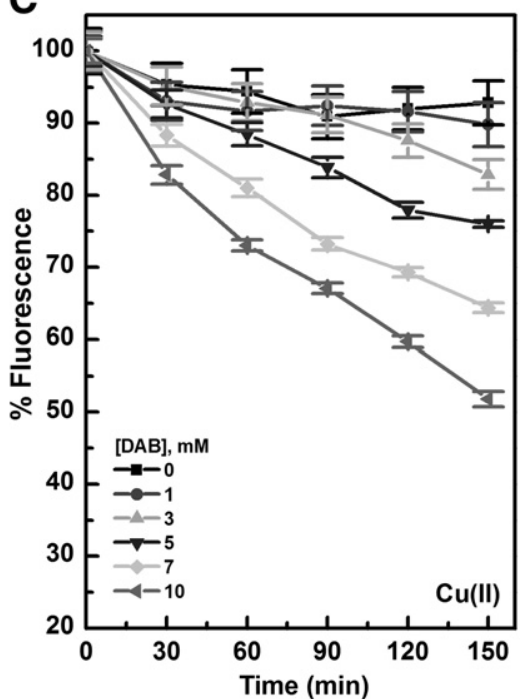

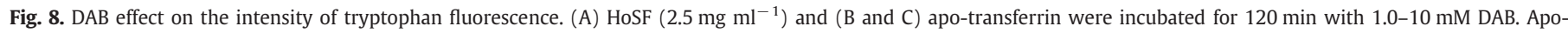
transferrin was incubated in the presence of $3 \mu \mathrm{M}$ Fe(II)EDTA (B) or $\mathrm{Cu}(\mathrm{II})(\mathrm{C})$. The data represent the mean values obtained from three independent experiments.

disorganization. Further studies are demanded to clarify the mechanism and organelle targets of DAB toxicity and pro-oxidative effects on T. cruzi cells. Here we show that DAB indeed causes peroxidation and permeabilization of biomimetic vesicles and covalent modifications of ferritin and apo-transferrin. Chemical damage to other proteins, DNA, and membranes by DAB as well as alterations in iron and copper homeostasis probably related to mitochondrial permeabilization can be anticipated for DAB from previous studies carried out with ALA and AA [6 and references therein]. In conclusion, we hypothesize that DAB is toxic to a different sort of cells, including mammalian cells, not only by interfering in their polyamine biosynthesis but also by altering their redox balance.

\section{Acknowledgments}

This work was supported by the Fundação de Amparo à Pesquisa do Estado de São Paulo, the Conselho Nacional de Desenvolvimento Científico e Tecnológico, the Coordenação de Aperfeiçoamento de Pessoal de Nível Superior, and the INCT Processos Redox em Biomedicina-Redoxoma. We are grateful to Dr. Brian Bandy (University of Saskatchewan, Saskatoon, SA. Canada) and Dr. Avishek Adhikari (Stanford University, Stanford, CA, USA) for kindly reading the manuscript and to Rita Tokikawa and Julio Massari Filho for helpful discussions and to Sandra M. Vaz for kindly providing DBNBS.
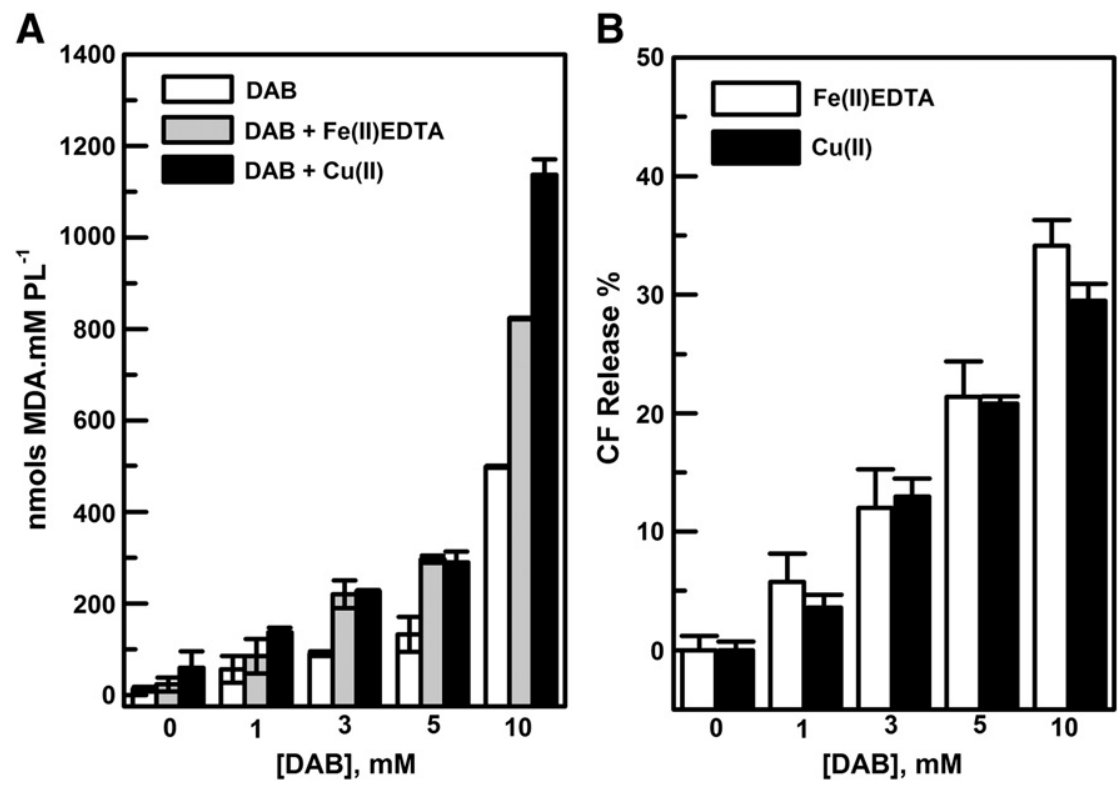

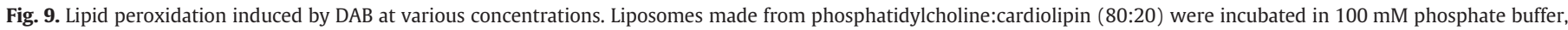

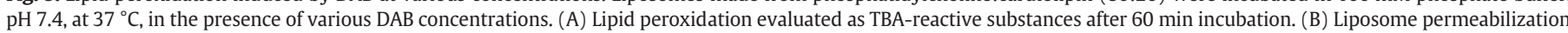
evaluated by the percentage of carboxyfluorescein released after $24 \mathrm{~h}$ incubation. The data represent the mean values obtained from three independent experiments. 
A

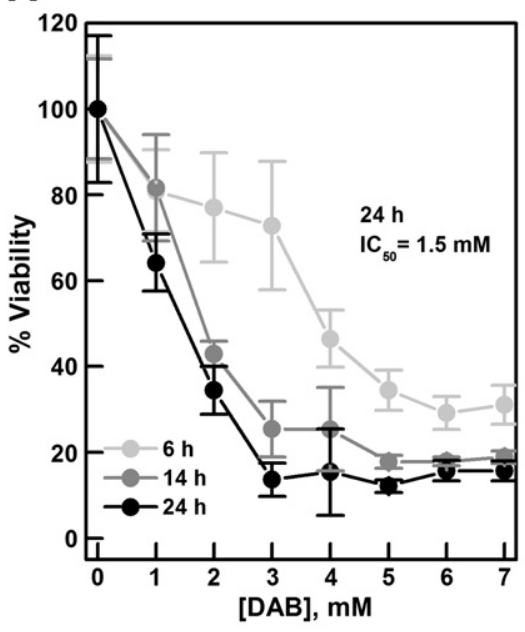

B

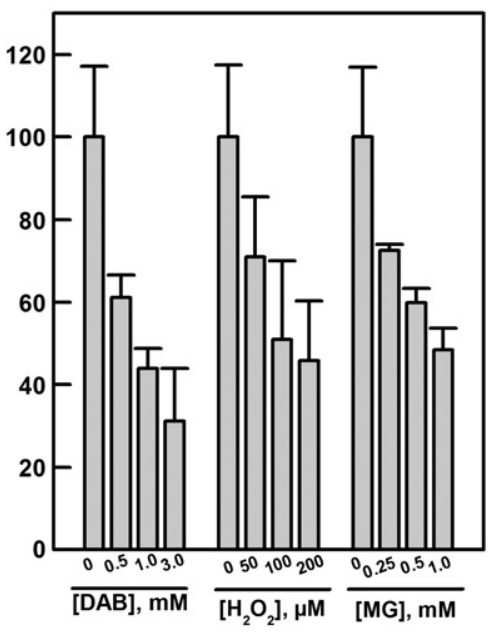

C

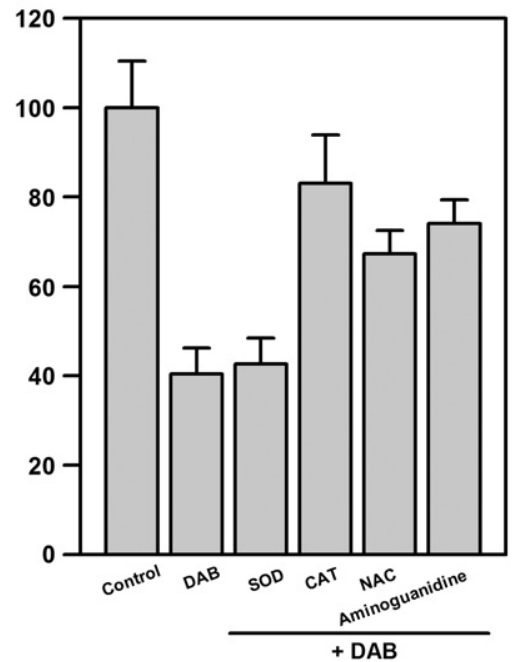

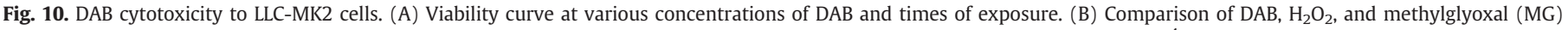

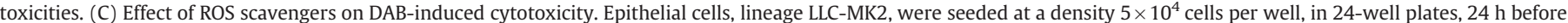

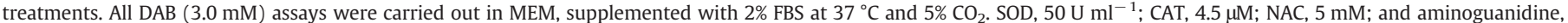

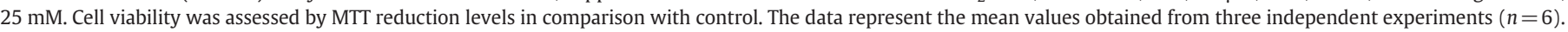

\section{References}

[1] Sassa, S. Modern diagnosis and management of the porphyrias. Br. J. Haematol. 135:281-292; 2006.

[2] Hindmarsh, J. T. The porphyrias: recent advances. Clin. Chem. 32:1255-1263; 1986.

[3] Kalapos, M. P. The tanden of free radicals and methylglyoxal. Chem. Biol. Interact. 171:251-271; 2008.

[4] Yu, P. H.; Wang, M.; Fan, H.; Deng, Y.; Gubisne-Haberle, D. Involvement of SSAOmediated deamination in adipose glucose transport and weight gain in obese diabetic KKAy mice. Am. J. Physiol. Endocrinol. Metab. 286:E634-E641; 2004.

[5] Dutra, F.; Knudsen, F. S.; Curi, D.; Bechara, E. J. H. Aerobic oxidation of aminoacetone, a threonine catabolite: iron catalysis and coupled iron release from ferritin. Chem. Res. Toxicol. 14:1323-1329; 2001.

[6] Bechara, E. J.; Dutra, F.; Cardoso, V. E.; Sartori, A.; Olympio, K. P.; Penatti, C. A.; Adhikari, A.; Assunção, N. A. The dual face of endogenous alpha-aminoketones: pro-oxidizing metabolic weapons. Comp. Biochem. Physiol. C Toxicol. Pharmacol. 146:88-110; 2007

[7] Douki, T.; Onuki, J.; Medeiros, M. H.; Bechara, E. J. H.; Cadet, J.; Di Mascio, P. Hydroxyl radicals are involved in the oxidation of isolated and cellular DNA bases by 5-aminolevulinic acid. FEBS Lett. 428:93-96; 1998.

[8] Douki, T.; Onuki, J.; Medeiros, M. H.; Bechara, E. J.; Cadet, J.; Di Mascio, P. DNA alkylation by 4,5-dioxovaleric acid, the final oxidation product of 5-aminolevulinic acid. Chem. Res. Toxicol. 11:150-157; 1998.

[9] Uchida, K. Role of reactive aldehyde in cardiovascular diseases. Free Radic. Biol. Med. 28:1685-1696; 2000.

[10] Thornalley, P. J. Dicarbonyl intermediates in the Maillard reaction. Ann. N.Y. Acad. Sci. 1043:111-117; 2005

[11] Menezes, D.; Valentim, C.; Oliveira, M. F.; Vannier-Santos, M. A. Putrescine analogue cytotoxicity against Trypanosoma cruzi. Parasitol. Res. 98:99-105; 2006.

[12] Vannier-Santos, M. A.; Menezes, D.; Oliveira, M. F.; Mello, F. G. The putrescine analogue 1,4-diamino-2-butanone affects polyamine synthesis, transport, ultrastructure and intracellular survival in Leishmania amazonensis. Microbiology 154:3104-3111 2008.

[13] Maia, C.; Lanfredi-Rangel, A.; Santana-Anjos, K. G.; Oliveira, M. F.; Souza, W.; Vannier-Santos, M. A. Effects of a putrescine analog on Giardia lamblia. Parasitol. Res. 103:363-370; 2008

[14] Reis, I. A.; Martinez, M. P.; Yarlett, N.; Johnson, P. J.; Silva-Filho, F. C.; VannierSantos, M. A. Inhibition of polyamine synthesis arrests trichomonad growth and induces destruction of hydrogenosomes. Antimicrob. Agents Chemother. 43: 1919-1923; 1999.

[15] Stevens, L.; McKinnon, I. M.; Winther, M. The effects of 1,4-diaminobutanone on polyamine synthesis in Aspergillus nidulans. FEBS Lett. 75:180-182; 1977.

[16] Bhattacharya, S.; Ray, R. M.; Johnson, L. R. Role of polyamines in p53-dependent apoptosis of intestinal epithelial cells. Cell Signaling 21:509-522; 2009.

[17] Bouchereau, A.; Aziz, A.; Larher, F.; Martin-Tanguy, J. Polyamines and environmental challenges: recent development. Plant Sci. 140:103-125; 1999.

[18] Kusano, T.; Berberich, T.; Tateda, C.; Takahashi, Y. Polyamines: essential factors for growth and survival. Planta 228:367-381; 2008.

[19] Augusto, O.; Bonini, M. G.; Amanso, A. M.; Linares, E.; Santos, C. C.; Menezes, S. L. Nitrogen dioxide and carbonate radical anion: two emerging radicals in biology. Free Radic. Biol. Med. 32:841-859; 2002.
[20] Itakura, K.; Osaka, T.; Uchida, K. Structure of a fluorescent compound formed from 4-hydroxy-2-nonenal and N-hippuryllysine: a model for fluorophores derived from protein modifications by lipid peroxidation. J. Org. Chem. 63:185-187; 2008.

[21] Oteiza, P. I.; Kleinman, C. G.; Demasi, M.; Bechara, E. J. H. 5-Aminolevulinic acid induces iron release from ferritin. Arch. Biochem. Biophys. 316:607-611; 1995.

[22] Bradford, M. M. A rapid and sensitive method for the quantitation of microgram quantities of protein utilizing the principle of protein-dye binding. Anal. Biochem. 72:248-254; 1979.

[23] Oteiza, P. I.; Bechara, E. J. H. 5-Aminolevulinic acid induces lipid peroxidation in cardiolipin-rich liposomes. Arch. Biochem. Biophys. 305:282-287; 1993.

[24] Fukunaga, K.; Yoshida, M.; Nakazono, N. A simple, rapid, highly sensitive and reproducible quantification method for plasma malondialdehyde by highperformance liquid chromatography. Biomed. Chromatogr. 12:300-303; 1998.

[25] Puntel, R. L.; Roos, D. H.; Grotto, D.; Garcia, S. C.; Nogueira, C. W.; Rocha, J. B. T. Antioxidant properties of Krebs cycle intermediates against malonate pro-oxidant activity in vitro: a comparative study using the colorimetric method and HPLC analysis to determine malondialdehyde in rat brain homogenates. Life Sci. 81: 51-62; 2007.

[26] Robinson, J.; Cooper, J. M. Method of determining oxygen concentrations in biological media, suitable for calibration of the oxygen electrode. Anal. Biochem. 33:390-399; 1970.

[27] Miller, D. M.; Buettner, G. R.; Aust, S. D. Transition metals as catalysts of autoxidation reactions. Free Radic. Biol. Med. 8:95-108; 1990.

[28] Qian, S. Y.; Buettner, G. R. Iron and dioxygen chemistry is an important route to initiation of biological free radical oxidations: an electron paramagnetic resonance spin trapping study. Free Radic. Biol. Med. 26:1447-1456; 1999.

[29] Mashino, T.; Fridovich, I. Superoxide radical initiates the autoxidation of dihydroxyacetone. Arch. Biochem. Biophys. 254:547-551; 1987.

[30] Monteiro, H. P.; Abdalla, D. S. P.; Augusto, O.; Bechara, E. J. H. Free radical generation during 5-aminolevulinic acid autoxidation: induction by hemoglobin and connections with porphyrinpathies. Arch. Biochem. Biophys. 271:206-216; 1989.

[31] Bruice, P. Y. Role of acidity of the ketone, carbinolamine, or imine: catalysis of enolization of 2,4-pentanedione and 3-methyl-2,4-pentanedione by oxyanions and by primary, secondary and tertiary amines. J. Am. Chem. Soc. 112:7361-7368; 1990.

[32] Bechara, E. J. H.; Oliveira, O. M. M. F.; Duran, N.; Baptista, R. C.; Cilento, G. Peroxidase catalyzed generation of triplet acetone. Photochem. Photobiol. 30: 101-110; 1979.

[33] Buettner, G. R. Spin trapping: ESR parameters of spin adducts. Free Radic. Biol. Med. 3:259-303; 1987.

[34] Su, M.; Yang, Y.; Yang, G. Quantitative measurement of hydroxyl radical induced DNA double-strand breaks and the effect of $\mathrm{N}$-acetyl-L-cysteine. FEBS Lett. 580: 4136-4142; 2006

[35] Okado-Matsumoto, A.; Fridovich, I. The role of alpha, beta-dicarbonyl compounds in the toxicity of short chain sugar. J. Biol. Chem. 275:34853-34857; 2000.

[36] Rocha, M. E. M.; Ferreira, A. M. D. C.; Bechara, E. J. H. Roles of phosphate and an enoyl radical in ferritin iron mobilization by 5 -aminolevulinic acid. Free Radic. Biol. Med. 29:1272-1279; 2000.

[37] He, Q. Y.; Mason, A. B.; Lyons, B. A.; Tam, B. M.; Nguyen, V.; MacGillivray, R. T; Woodworth, R. C. Spectral and metal-binding properties of three single-point tryptophan mutants of the human transferrin N-lobe. Biochem. J. 354:423-429; 2001.

[38] Thornalley, P. J. Use of aminoguanidine (Pimagedine) to prevent the formation of advanced glycation end products. Arch. Biochem. Biophys. 419:31-40; 2003. 
[39] Brunton, V. G.; Grant, M. H.; Wallace, H. M. Mechanisms of spermine toxicity in baby-hamster kidney (BHK) cells: the role of amine oxidases and oxidative stress. Biochem. J. 280:193-198; 1991.

[40] Calvo-Méndez, C.; Villagómez-Castro, J. C.; López-Romero, E. Ornithine decarboxylase activity in Entamoeba invadens. Int. J. Parasitol. 23:847-852; 1993.

[41] Ueno, Y.; Fukumatsu, M.; Ogasawara, A.; Watanabe, T.; Mikakami, T.; Matsumoto, T. Hyphae formation of Candida albicans is regulated by polyamines. Biol. Pharm. Bull. 27:890-892; 2004

[42] Abordo, E. A.; Minhas, H. S.; Thornalley, P. J. Accumulation of $\alpha$-oxoaldehydes during oxidative stress: a role in cytotoxicity. Biochem. Pharmacol. 58:641-648; 1999.

[43] Halliwell, B.; Gutteridge, J. M. C. Free Radicals in Biology and Medicine, 4th edition. Oxford Univ. Press, New York; 2007.

[44] Doherty, C. P. Host-pathogen interactions: the role of iron. J. Nutr. 137: 1341-1344; 2007.

[45] Wilson, M. E.; Britigan, B. E. Iron acquisition by parasitic protozoa. Parasitol. Today 14:93-95; 1998.

[46] Crichton, R. R.; Declercq, J. P. X-ray structures of ferritins and related proteins. Biochim. Biophys. Acta 1800:706-718; 2010.
[47] Harrison, P. M.; Arosio, P. M. The ferritins: molecular properties, iron storage function and cellular regulation. Biochim. Biophys. Acta 1275:161-203; 1996.

[48] Dutra, F.; Araki, D.; Bechara, E. J. H. Aminoacetone induces loss of ferritin ferroxidase and iron uptake activities. Free Radic. Res. 37:1113-1121; 2003.

[49] Rocha, M. E. M.; Dutra, F.; Bandy, B.; Baldini, R. L.; Gomes, S. L.; Faljoni-Alario, A. Líria, C. W.; Miranda, M. T. M.; Bechara, E. J. H. Oxidative damage to ferritin by 5aminolevulinic acid. Arch. Biochem. Biophys. 409:349-356; 2003.

[50] Kohgo, Y.; Ikuta, K.; Ontake, T.; Torimoto, Y.; Kato, J. Body iron metabolism and pathophysiology of iron overload. Int. J. Hematol. 88:7-15; 2008.

[51] Stefanini, S.; Chiancone, E.; Arosio, P.; Finazzi-Agro, A.; Antonini, E. Structural heterogeneity and subunit composition of horse ferritins. Biochemistry 21: 2293-2299; 1982.

[52] Agostinelli, E.; Arancia, G.; Vedova, L. D.; Belli, F.; Marra, M.; Salvi, M.; Toninello, A The biological functions of polyamine oxidation products by amine oxidases: perspectives of clinical applications. Amino Acids 27:347-358; 2004

[53] Seiler, N. Catabolism of polyamines. Amino Acids 26:217-233; 2004

[54] Manen, C. A.; Russell, D. H. Regulation of RNA polymerase I activity by ornithine decarboxylase. Biochem. Pharmacol. 26:2379-2384; 1977. 